\title{
FURTHER OBSERVATIONS OF GREAT-CRESTED FLYCATCHERS
}

JEAN BANCROFT, 306-200 Tuxedo Avenue, Winnipeg, Manitoba. R3P OR3

For the past three summers I have been privileged to observe the entire nesting period of Great-crested Flycatchers. Since my detailed report in Blue Jaw of the nesting of this species in 1981 I have been able to make a few more interesting observations.

On 4 June 1982, as we entered the gate to our property at Whytewold on Lake Winnipeg, I heard a pair of these birds and watched while one of them examined the same box inhabited by Cresteds in 1981. The next day they returned and nest building commenced. I was not, however, able to determine if both sexes build, but $\mathrm{Hal}$ Harrison says they do. ${ }^{4}$

At various times during incubation, when the female flew out of the box, I noticed that the male appeared on the stoop and peered in, but I did not ever see him enter the box until the young had hatched. On several occasions I observed that, when an adult carried the feces from the nest box, its flight pattern was belaboured; it swooped down low and then rose higher (like an aeroplane) and sometimes flew 18 to $21 \mathrm{~m}$ away from the box.

By 17 July the nesting had been completed successfully. The parents, with their three fledglings, remained in the area until 17 August, which was the last day I heard their calls.

Then, in the spring of 1983, Greatcresteds arrived again on our property. Bent says, "The impression seems to prevail that passerine birds sellect new mates each year, but evidently this is not always the case with the Crested which seems to show great attachment to its home territory and, sometimes, to its former mate." 2

This time, however, there was a frantic three-bird chase. On 9 and 10 June the temperature was $27^{\circ} \mathrm{C}$ and the birds kept up their unbelievably swift chase for hours at a time; I thought that one or other might collapse from exhaustion. Their incessant raucous calls could be heard all over the neighbourhood. One bird flew into an empty shallow nestbox several times and another flew at this bird. Several times the three birds flew around the box used by a pair in 1981 and 1982 but, unfortunately, this box had been chosen by a pair of Tree Swallows a few days earlier. Needless to say, the Tree Swallows were ever on the alert in case one of the Cresteds tried to investigate the entrance to the nest box.

Fortunately, there was another suitable box available; it was attached to an old poplar tree about $4.5 \mathrm{~m}$ from the original box, but deeper into the wooded area. On 16 June I finally noticed, through the thick foliage, that a Crested came out of this particular box.

9 July, during the period when the adults were feeding the young, I was greatly disturbed to find a dead Crested male on the grass close to a driveway across the road from our cottage. For a few hours it seemed that my hopes for a successful nesting had vanished. However, the next day I was very relieved to see two adults making frequent trips to feed the nestlings in our box. (The thought had occurred to me at that time that the dead male might have been the other male which took 
part in the three-bird chase.)

I have been particularly interested in the materials used in nest construction. A search of literature reveals that a piece of cast-off snakeskin is frequently used in the building of the Cresteds' nests. Detailed account of the contents of the 1981 nest has already appeared in Blue Jay'.

The 1982 nest had a peat moss base (as in 1981), bits of dead leaves and brown paper, a length of brown string, a narrow strip of raccoon fur, and one infertile egg.

The 1983 nest had some very small wood chips at the base, dried weed stems, grasses, several black feathers, small pieces of American Robin eggshell, a small piece of waxpaper, a few strips of shredded newspaper and, in one corner at the side of the cup, was a piece of muskrat belly fur. In none of the three nests was there a piece of the proverbial snakeskin.

In 1939 A.G. Lawrence stated that in different areas of Winnipeg a person "found three nests but no cast-off snake's skin decorated the entrance holes, as is often the case in the eastern states." "Godfrey mentions that "there has been considerable speculation as to why the Crested so frequently places a piece of cast-off skin in its nest..."3 Henry Mousley states that a nest he observed in 1932 in Quebec had "a quantity of fine animal fur ... but no signs whatever of the proverbial snakeskin."6

In this regard Bent states "there can be no doubt that such old skins are often, perhaps generally, found in the nests, though they are usually found in small pieces and are often entirely lacking or replaced with something else of similar texture."2 Vaiden says "that from a total of 37 nests examined in the past 30 years, snakeskins have been found in only 14."2 Prof. Maurice Brooks says of one nest, "The birds had evidently been unable to find the pieces of snakeskin, which they are accustomed to place in their nests, but in this case they had substituted 3 pieces of the yellowed outside skin of an onion. This is the only nest I have evern seen that did not contain at least one piece of snakeskin."2

Apparently, the reason for the use of snakeskin remains unknown. Hal Harrison states that the "theory that snakeskins are used in nest to frighten away predators unacceptable. Probably that bird does not recognize snakeskin as such; that it is used along with other available trash as desirable material." "4 Bent agrees and adds, "The fact that the Crested has been found so often using such material as onion skins, thin, greasy, or waxed paper ... suggests that either these bright shiny substances attract their attention, or that they, like snakeskins, furnish a certain degree of resiliency, or perhaps ventilation, in the nest." 2 John $\mathrm{K}$. Terres mentions snakeskin, along with the other usual material, and then states, "cellophane and onion skins apparently because of shininess comparable to that of snakeskin."7

I am looking forward to the spring of 1984 with the hope that I shall be able to make further observations of the nesting habits of this interesting member of the Flycatcher family.

I wish to thank Mr. Herb Copland and Dr. Kenneth Wrigley for examining the nests.

'BANCROFT, JEAN. 1981. Great-crested Flycatcher. Blue Jay 39(4):226-227.

BENT, ARTHUR C. 1963. Life histories of North American flycatchers, larks, swallows and their allies. Dover reprint. New York. 555 pp.

${ }^{3}$ GODFREY, W.E. 1966. The birds of Canada. Nat. Mus Canada Bull. 203.

${ }^{4 H A R R I S O N}$, H.H. 1975. A field guide to birds' nests in the United States east of 
the Mississippi River. Houghton Mifflin, Boston. 257 pp.

${ }^{5}$ LAWRENCE, A.G. 1939. More Winnipeg nesting reports. Chickadee Notes No. 960, Winnipeg Free Press, 18 August 1939.
${ }^{6}$ MOUSLEY, HENRY. 1934. A study of the home life of the Northern Crested Flycatcher. Auk Vol LI:207-216.

TTERRES, JOHN K. Ed. 1980. Audubon Society encyclopedia of North American birds. Knopf, New York. 1280 pp.

\section{EASTERN BLUEBIRD NESTBOX REPORT}

L.A. SMITH, \#303, 481 Vaughan Road, Toronto, Ontario. M6C 2P6

The season of 1983 was disappointing. Doubly so since we dug in 140 new posts, wrapped metal around these posts to keep out raccoons and other pests and made new boxes and reworked and cleaned the older boxes. The figure of 114 good nestings is the same as 1982. We can take consolation from the fact that we are not going backwards!

However we are puzzled by the unknown factors which prevented an increase in successful nests. Cold weather in May, the aggressive behaviour of 400 pairs of Tree Swallows, wrens puncturing or removing eggs, poisonous sprays along country roads ... all might be factors keeping bluebirds rare. If we did expand into arable land and cities a trap to kill weaver finches (House Sparrows) would become necessary. These pests are the main reason for the poor showing of the bluebird of happiness.

Bill Read banded a total of 107 birds in the nestboxes. This is the highest number banded so far.

Table 1. YOUNG EASTERN BLUEBIRDS IN NESTBOXES, 1983*

$\begin{array}{lc}\text { Location } & \text { Brood } \\ \text { Adjala } & 1 \\ \text { Adjala } & 2 \\ \text { Caledon/Albion } & 1 \\ \text { Caledon/Albion } & 2 \\ \text { Great Pine Ridge } & 1 \\ \text { Great Pine Ridge } & 2 \\ \text { Mono } & 1 \\ \text { Mono } & 2 \\ \text { Mulmur } & 1 \\ \text { Mulmur } & 2 \\ \text { Tosorontio } & 1 \\ \text { Tosorontio } & 2\end{array}$

Totals

\begin{tabular}{c} 
No. Nests \\
6 \\
2 \\
14 \\
3 \\
8 \\
6 \\
28 \\
20 \\
14 \\
6 \\
6 \\
1 \\
\hline 114
\end{tabular}

No. Young 23 8 57 10 39 25 121

70

60

18

27

$\frac{4}{462}$ 